\title{
PMP22 related neuropathies: Charcot-Marie-Tooth disease type 1A and Hereditary Neuropathy with liability to Pressure Palsies
}

Barbara W van Paassen ${ }^{{ }^{*}}$, Anneke J van der Kooi ${ }^{2}$, Karin Y van Spaendonck-Zwarts ${ }^{1}$, Camiel Verhamme ${ }^{2}$, Frank Baas ${ }^{3}$ and Marianne de Visser ${ }^{2}$

\begin{abstract}
PMP22 related neuropathies comprise (1) PMP22 duplications leading to Charcot-Marie-Tooth disease type 1A (CMT1A), (2) PMP22 deletions, leading to Hereditary Neuropathy with liability to Pressure Palsies (HNPP), and (3) PMP22 point mutations, causing both phenotypes. Overall prevalence of CMT is usually reported as 1:2,500, epidemiological studies show that 20-64\% of CMT patients carry the PMP22 duplication. The prevalence of HNPP is not well known. CMT1A usually presents in the first two decades with difficulty walking or running. Distal symmetrical muscle weakness and wasting and sensory loss is present, legs more frequently and more severely affected than arms. HNPP typically leads to episodic, painless, recurrent, focal motor and sensory peripheral neuropathy, preceded by minor compression on the affected nerve. Electrophysiological evaluation is needed to determine whether the polyneuropathy is demyelinating. Sonography of the nerves can be useful. Diagnosis is confirmed by finding respectively a PMP22 duplication, deletion or point mutation. Differential diagnosis includes other inherited neuropathies, and acquired polyneuropathies. The mode of inheritance is autosomal dominant and de novo mutations occur. Offspring of patients have a chance of 50\% to inherit the mutation from their affected parent. Prenatal testing is possible; requests for prenatal testing are not common. Treatment is currently symptomatic and may include management by a rehabilitation physician, physiotherapist, occupational therapist and orthopaedic surgeon. Adult CMT1A patients show slow clinical progression of disease, which seems to reflect a process of normal ageing. Life expectancy is normal.
\end{abstract}

Keywords: Peripheral myelin protein 22 (PMP22), Charcot-Marie-Tooth disease type 1A (CMT1A), Hereditary Motor and Sensory Neuropathy type la (HMSN la), Hereditary Neuropathy with liability to Pressure Palsies (HNPP), Demyelinating, Clinical description, Genetic counselling

\section{Introduction}

PMP22 related neuropathies can be divided in three groups. The first group is caused by a PMP22 duplication, and constitutes the majority of Charcot-MarieTooth disease type 1A (CMT1A). The second group is caused by a PMP22 deletion, leading to Hereditary Neuropathy with liability to Pressure Palsies (HNPP). The third group is composed of neuropathies related to point mutations in the $P M P 22$ gene and is classified as CMT1A or CMT1E.

\footnotetext{
* Correspondence: b.w.vanpaassen@amc.uva.nl

'Department of Clinical Genetics, Academic Medical Center, Meibergdreef 9 $1105 \mathrm{AZ}$, Amsterdam, the Netherlands

Full list of author information is available at the end of the article
}

\section{PMP22 duplication - Charcot-Marie-Tooth disease type 1A (CMT1A) \\ Disease name}

Charcot-Marie-Tooth disease type 1A (CMT1A). Synonyms: Hereditary Motor and Sensory Neuropathy type Ia (HMSN Ia). Orphanumber ORPHA101081.

\section{Definition}

Charcot-Marie-Tooth disease (CMT), also known as Hereditary Motor and Sensory Neuropathy (HMSN) [1], encompasses a clinically and genetically heterogeneous group of disorders characterized by predominantly distal muscle weakness and atrophy, and sensory loss. The 
disease was first described in 1886 by Charcot and Marie in France and independently by Tooth in Great Britain and was named after them [2,3]. CMT is the commonest inherited neuromuscular disorder. More than 45 causative genes have been identified $[4,5]$. Despite the genetic heterogeneity, the clinical phenotype is relatively homogeneous [6]. Classification is based on a combination of neurophysiologic characteristics, inheritance pattern, and underlying genetic cause [7]. Based on neurophysiologic findings three different subtypes are distinguished, i.e. the demyelinating type (CMT1) defined by a motor conduction velocity (MCV) of the median or ulnar nerve of less than $38 \mathrm{~m} / \mathrm{s}$, the axonal type (CMT2) with MCV above $38 \mathrm{~m} / \mathrm{s}[8]$, and an intermediate type [9,10]. The existence of the latter is a controversial topic. Several definitions exist for the term "intermediate". It has been used in individuals with a MCV between 30 and $40 \mathrm{~m} / \mathrm{s}$ $[10,11]$, in individuals with clinical and histopathological evidence of both abnormal myelin and axon abnormalities [11,12] and in families in which members have either a demyelinating phenotype or an axonal phenotype, like families with X-linked CMT due to GJB1-mutations, with male members showing a demyelinating type and female an axonal type $[9,13]$. CMT can be inherited in an autosomal dominant, autosomal recessive and X-linked manner. Previously, histopathological features were also applied to distinguish demyelinating from axonal neuropathy $[1,14]$. However, nowadays, a nerve biopsy for diagnosis is considered to be obsolete. Further subclassification is based on the underlying genetic cause. CMT1A is the most common subtype of CMT1. This autosomal dominantly inherited demyelinating form of CMT is caused by a $1.5 \mathrm{Mb}$ duplication on chromosome 17p11.2 [15,16], containing the gene coding for peripheral myelin protein 22 (PMP22) and thus leading to three copies of the PMP22 gene [17-20].

\section{Epidemiology}

Overall prevalence of CMT is usually reported as $1: 2,500$ [21]. Several more recent epidemiological studies [22-25] reported prevalences of CMT ranging from $1: 1,214$ (in Norway) to $1: 6,500$ (in the United Kingdom). Epidemiological studies show that $19.6 \%$ to $64.7 \%$ of CMT patients carry the PMP22 duplication [22,25], which gives calculated prevalences of CMT1A in the range of 1:3,800 to $1: 12,500$.

\section{Clinical description}

The age of onset of CMT1A is mainly in the first two decades [26,27] and most frequently in the first 10 years of life [26-30]. Exceptions occur as onset at birth as a floppy infant [28] or with congenital foot deformities [26,31]. Late onset at 76 years [27] is mentioned and a case report describing siblings diagnosed at age 69 and
65 years [32]. CMT1A usually presents as the "classical CMT" phenotype $[7,26]$. The typical presenting symptom is difficulty walking or running, due to weakness of the distal leg muscles [26,28,33]. CMT patients usually have distal symmetrical muscle weakness and wasting, legs ("stork appearance") more frequently and more severely affected than arms. Calf hypertrophy instead of atrophy may also be found [26,28,29]. Proximal weakness can be observed in up to $28 \%$ in knee extensors [27-29,34,35]. Foot deformity, usually pes cavus with hammertoes, is a cardinal feature in CMT1A patients, with up to $90 \%$ of patients presenting with pes cavus [29]. In about one third of patients this can be the presenting symptom [26]. Clawing of the hands may occur, but is usually milder. Skeletal deformity of the spine (scoliosis) is reported in 4-35\% of patients [26-29]. Upper extremity symptoms include muscle weakness, primarily of intrinsic muscles, and atrophy. Decreased manual dexterity was found to be a common finding among subjects with CMT1A [36]. Sensory symptoms are usually less prominent and can be subtle $[8,26,37,38]$. Impaired sensation is usually found in a stocking-glove distribution with the legs more frequently and more severely affected than the arms. Large fibre sensory involvement leads to proprioceptive loss, causing balance difficulties [37]. Small fibre sensory loss can be present with complaints of cold feet and decreased temperature discrimination sense [37]. Pain in CMT patients is more common than previously recognized, with $55-70 \%$ of CMT1A patients reporting pain $[39,40]$, which is considered predominantly nociceptive. Severe fatigue is reported in $60 \%$ of adult patients [41] and is also reported in children $(24 \%$, in contrast to $14 \%$ of general school-based population) [42]. Tremor, especially of the hands, can be a feature [26-29,37]. In some cases the tremor can be quite severe. Several CMT1A patients with tremor are described as having a Roussy-Lévy phenotype [26,43,44]. However, the original Roussy-Lévy family carried a mutation in the MPZ gene [45]. Nonprogressive sensorineural hearing impairment is described in CMT1A patients [46]. Sixty-one percent of the paediatric CMT1 patients (16/18 with PMP22 duplication) showed significantly impaired speech perception ability, although they showed normal or nearnormal sound detection [47]. Vestibular impairment seems to be frequent in patients with CMT [48]. Phrenic nerve involvement, causing dyspnoea when lying flat or nocturnal hypoventilation, is infrequent in CMT1A, but has been reported in some, severely affected, patients (in $5 \%$ [26] and 3.5\% [28], respectively). CMT may predispose to obstructive sleep apnoea [49]. Only rarely patients have normal reflexes, mostly they are absent (in up to $46-75 \%$ of patients) or depressed [26-29]. Hypertrophy of nerves is a feature of CMT1A, rarely clinically present and mostly established by pathology [44] or imaging studies [50-53]. 
There is large clinical variability between patients, even within the same family $[54,55]$. Overall, $1-7 \%$ of patients become wheelchair dependent $[27,28,35]$. A walking aid (cane, crutches or walker) is needed by $3-14 \%$ of patients $[27,28,35,38]$. Dejerine-Sottas syndrome (in the past also known as Hereditary Motor and Sensory Neuropathy type III) is a hereditary neuropathy with early onset and severe presentation. Currently it is not considered a different entity, but part of the phenotypic spectrum of CMT1, because the underlying genetic defects are known CMT1 genes, like the PMP22 duplication [56,57]. There are case reports on severely affected CMT patients demonstrating the presence of two mutations in two different CMT-related genes ("double trouble") [58,59]. On the other side of the spectrum, patients can be asymptomatic (1.6\% to $17 \%$ [26-28]) or only exhibit mild symptoms, like foot deformity, leading to no or only mild problems with walking [26,27]. However the term asymptomatic is questionable, as asymptomatic individuals might not experience complaints but clinical examination may show pes cavus and/or ankle jerk areflexia [27].

Although always considered a disease affecting the peripheral nervous system, a recent report on 15 CMT1A patients described central nervous system involvement [60]. Decreased white matter volume was found in $73 \%$, with minimal, predominantly executive, cognitive disorders in $77 \%$.

Electrophysiologically, CMT1A is characterized by a homogeneous and diffuse motor and sensory nerve conduction slowing $[6,27,38,54,61,62]$. Due to a combined effect of dysmyelination and axonal dysfunction and loss, sensory nerve action potentials (SNAP) are also frequently reduced in the arms and reduced to absent in the legs $[27,29,38]$.

Nerve biopsies show decreased density of myelinated nerve fibres, most pronounced in biopsies taken in the first year of life. The mean g-ratio (axon diameter versus fibre diameter) is significantly lower than normal [63]. Characteristic onion bulb formation occurs after the age of six [44,63-65]. Axonal loss is also found in childhood [65]. Abnormal myelination probably extends over the whole nerve length. The most severe pathological changes were seen distally in nerves, but there were also changes in the proximal nerves and in the roots [66].

An overview of the key features of CMT1A is presented in Table 1.

\section{Aetiology}

CMT1A is predominantly caused by a $1.5 \mathrm{Mb}$ duplication on chromosome $17 \mathrm{p} 11.2[15,16]$ that includes the PMP22 gene [17-20]. Cases of CMT1A with different sized duplications, most including the PMP22 gene $[67,68]$ or a copy number variant upstream of PMP22 are reported [69]. Occasionally $(<5 \%)$ point mutations in the gene are found (see "PMP22 point mutations"). Mutations in the PMP22 gene had previously been identified as the Trembler mouse mutation. Identification of an identical mutation in a CMT family showed that the PMP22 gene is also responsible for CMT1A [70].

Gene dosage of PMP22 is the proposed mechanism, supported by the finding that increased PMP22 protein [71] and elevated PMP22 messenger RNA (mRNA) was found in CMT1A patients in sural nerve biopsies [72]. The PMP22 gene encodes a $22-\mathrm{kD}$ protein that comprises 2 to $5 \%$ of peripheral nervous system myelin. PMP22 is produced primarily by Schwann cells. It is expressed in the compact portion of essentially all myelinated fibres in the peripheral nervous system [73]. The exact function of PMP22 is still not elucidated. Studies in injured nerve suggested a role during Schwann cell growth and differentiation [73].

CMT1A has been considered a primary demyelinating neuropathy, as also shown by low conduction velocities on electrophysiology in CMT1A patients. However, it has become clear that axonal dysfunction determines clinical disease severity $[35,38,74,75]$. Onion bulbs seen on morphological studies of nerve biopsies are a sign of de- and remyelination. Evidence is accumulating that CMT1A might be a disorder of dysmyelination instead of demyelination, meaning myelination is delayed and normal myelination is never reached [76-79].

\section{Diagnosis (diagnostic criteria and algorithms) and diagnostic methods}

If a patient presents with a chronic motor and sensory polyneuropathy, CMT should be one of the differential diagnoses. In the assessment of any patient with a polyneuropathy, the first issue to consider is whether the polyneuropathy is hereditary, by taking a detailed family history about polyneuropathies, walking difficulties or pes cavus. The mode of inheritance is autosomal dominant, but one should be aware of asymptomatic or non-diagnosed family members and a de novo rate of $10 \%[80,81]$.

Electrophysiologic evaluation is needed to determine whether the polyneuropathy is demyelinating, axonal or intermediate. Sonography of median nerves can be helpful. It was shown that median nerve cross-sectional area (CSA) was significantly increased in CMT1A compared to CMT2 [50,52,53], and CSA correlated with nerve conduction slowing in CMT1A [52].

In autosomal dominantly inherited uniformly demyelinating sensorimotor polyneuropathy, the PMP22 duplication, the most common cause of CMT1, is tested first. In severe cases "double trouble" (the presence of two mutations in two different CMT-related genes) can be present. Currently, with the knowledge and easy accessibility of DNA diagnostics, nerve biopsy is obsolete. 
Table 1 Key features of CMT1A and HNPP

\begin{tabular}{lll}
\hline & CMT1A & HNPP \\
& Duplication of PMP22 & Deletion of PMP22 \\
\hline Clinical features & Age of onset mainly in first two decades & Painless attacks of numbness, muscular weakness, \\
& Presenting symptom is difficulty walking or running & and atrophy, recurrent and focal \\
& Distal symmetrical muscle weakness and wasting, & Preceded by minor compression on nerve \\
& legs $>$ arms & Age at onset mostly in the second or third decade \\
& Pes cavus very frequent & Pes cavus found in 4-47\% of patients \\
& Sensory symptoms (stocking-glove distribution) usually & Full recovery in 50\% of episodes, usually in days \\
& less prominent, legs > arms & to weeks \\
& Pain more common than previously recognized & Sequelae rarely severe \\
& Reflexes absent or depressed & Large intrafamilial clinical variability \\
Electrophysiological & Large clinical variability between patients, even within family \\
features & Homogeneous and diffuse MCV and SCV slowing & Increase in distal motor latencies, especially of median \\
CMAP amplitudes reduced, especially distally in the legs & and peroneal nerve \\
& SNAP amplitudes frequently reduced to absent & Focal motor slowing at entrapment sites \\
& & MCV normal to slightly reduced in other segments \\
Neuropathological & Abnormal myelination over the whole nerve length \\
features & Onion bulbs & SCV decreased and SNAP amplitudes often reduced \\
& Decreased density of myelinated nerve fibres & Segmental de-and remyelination
\end{tabular}

$\mathrm{CMAP}=$ compound muscle action potential. $\mathrm{MCV}=$ motor conduction velocity. SCV = sensory conduction velocity. SNAP = sensory nerve action potentials.

\section{Differential diagnosis}

Also in a patient without a positive autosomal dominant family history presenting with a uniformly demyelinating sensorimotor polyneuropathy, CMT1A should be considered and tested first. If DNA-testing for the PMP22 duplication is negative, other forms of CMT1 should be considered. An algorithm for genetic testing of patients with demyelinating polyneuropathy is presented in Figure 1. In view of the large number of genes involved in CMT, a gene by gene analysis is time consuming. With the introduction of Next Generation Sequencing (NGS) in clinical diagnostics the development of NGS panels for CMT is expected [82-84]. The first diagnostic step in patients with demyelinating polyneuropathy should remain testing for PMP22 duplication. If negative, all the genes should be sequenced in one run (panel). Whole exome sequencing (WES) is not recommended as a first screen since the costs are still high and the sensitivity of this technology is not yet high enough. WES should only be applied to those familial cases where screening of the affected family members has proven negative. The results of the NGS panel should be discussed with geneticists with expertise in the CMT-area. Key issue in the analysis is the likelihood of the sequence variant to be pathogenic and to correspond with the patient's phenotype and inheritance pattern. This incorporates cosegregation analysis in affected family members. If technical resources or expertise for NGS is not available, a candidate gene approach is also presented in Figure 1.
Demyelinating polyneuropathy can also be a sign of autosomal recessive metachromatic leucodystrophy [85], Refsum's disease [86], Krabbe's disease [87], X-linked adrenomyeloneuropathy [88], Pelizaeus-Merzbacher syndrome [89] and Lowe syndrome [90], but in addition other characteristic symptoms and signs will be present. Acquired causes associated with segmental demyelinating neuropathy, e.g. diabetes mellitus, and chronic inflammatory demyelinating polyneuropathy (CIDP) should also be considered. Typically, CIDP shows a subacute or fluctuating course, multi-focal demyelinating features on electrophysiology, high protein levels in cerebrospinal fluid, no pes cavus and a negative family history [91,92]. However, in clinical practice, symptoms of CIDP and CMT can overlap [93]. Establishing the diagnosis is important, since CIDP is treatable. Diabetes mellitus is the most common cause of neuropathy [94] and should always be considered in a polyneuropathy patient. A distal symmetrical sensory polyneuropathy is the most common pattern of diabetic neuropathy [95]. Diabetic neuropathy is usually axonal, but can also show demyelinating features on electrophysiology [91]. As opposed to CMT, diabetic neuropathy has predominantly sensory and autonomic manifestations [94].

\section{Genetic counselling and antenatal diagnosis}

CMT1A is inherited in an autosomal dominant fashion. Thus offspring of CMT1A patients have a chance of 50\% to inherit the PMP22 duplication from their affected parent. Anticipation is described in several case studies 


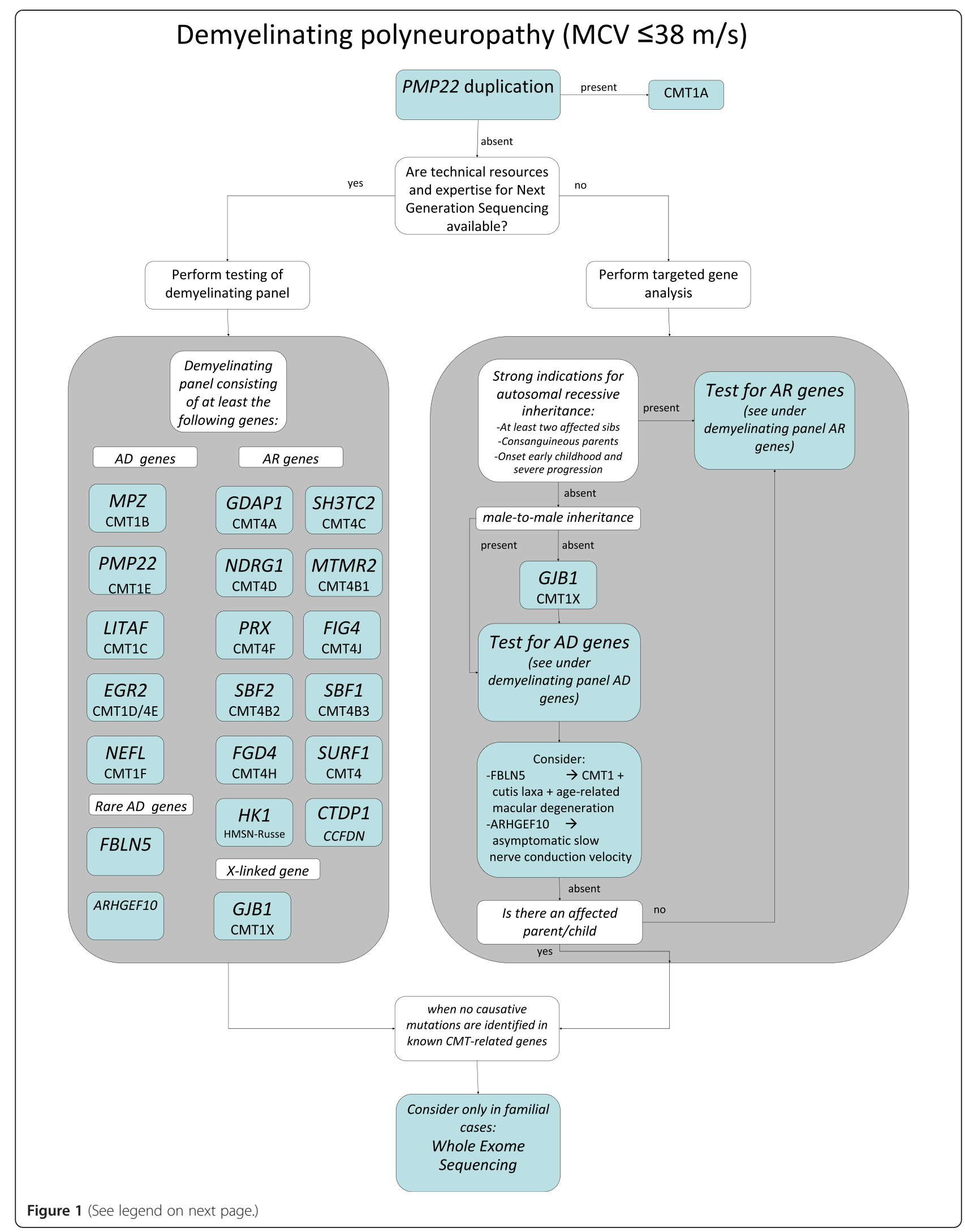


[96-98]. However, in our opinion this rather reflects phenotypic variability within a family, which is a well known phenomenon in CMT1A [54,55]. The variability is likely, at least in part, due to genetic modifiers (see section "unresolved questions").

When the diagnosis of an inherited condition is made in a family, issues like family planning and testing of relatives at risk can arise. The best way of handling these issues, is nondirective counselling. This is based on the autonomy of the patient to make the decision that serves his/her best interests, after receiving nondirective information about benefits and disadvantages of testing, considering for instance family planning, work related choices and insurance issues. If clinically unaffected family members request predictive testing and are found to carry the PMP22 duplication, it is likely that they will develop some features, since the penetrance of the disease is nearly 100\% [99]. There is consensus about not testing minors at risk of an inherited disorder without treatment or preventive options, because of the chance of psychological harm to the child [100,101]. Prenatal testing on foetal DNA is possible. During pregnancy foetal DNA can be obtained by chorionic villus sampling or by amniocentesis, both with a risk of miscarriage due to the sampling. Requests for prenatal testing for conditions that do not affect life span or intellect are not common. Requests for prenatal testing should be managed in a multidisciplinary team, involving genetic counsellors, psychologists and (paediatric) neurologists [102]. Pre-implantation Genetic Diagnosis (PGD) is a technique used to identify genetic defects in embryos created through in vitro fertilization before pregnancy. PGD is sparsely undertaken for CMT1A [103]. In some countries it is not considered an indication for PGD [104].

\section{Management including treatment}

Treatment consists of supportive care and may include management by a rehabilitation physician, physiotherapist, occupational therapist and orthopaedic surgeon.

Supportive care for the legs includes exercise training, shoe inlays, orthopaedic shoes and orthoses. In case of severe skeletal deformities surgical correction may be considered. However, evidence is limited; a Cochrane review concluded that methodologically sound trials are required for any of these physical interventions [105,106]. Orthopaedic surgery to correct severe pes cavus or hammertoes may be helpful [107-109]. Likewise, robust evidence is not present. Symptomatic treatment for the arms has not been studied extensively. Wearing a thumb opposition splint may improve manual dexterity in CMT [110]. Tendon transfer surgery is moving a tendon from its original attachment to a new one to restore the action of the transferred muscle and improve function. It may improve thumb opposition of patients with CMT [111,112]. Symptomatic drug treatment for positive sensory symptoms and for muscle cramps may be useful, but has not been investigated specifically for CMT.

Co-existence of diabetes mellitus in a CMT1A patient is described to exacerbate symptoms of the peripheral neuropathy [113,114], and therefore optimal control of blood sugar should be strived for in a CMT patient with diabetes. Toxin or medication-induced worsening of pre-existing peripheral neuropathy is a generally known phenomenon [115]. The use of neurotoxic agents, especially vincristine, can have a devastating effect, even in low dose $[116,117]$ and should be avoided in patients with CMT.

Perspectives on future therapeutic developments are discussed in the "unresolved questions" section.

\section{Prognosis}

As mentioned, axonal dysfunction determines clinical disease severity $[35,38,74,75]$. Nerve conduction velocities are found to remain stable in children after the age of six years $[35,77,118,119]$. There are only a few natural history studies done in adult CMT1A patients $[35,118,120]$, all showing slow clinical progression. Only one 5-year natural history study included age-matched controls [35] and showed that baseline strength and compound muscle action potential (CMAP) amplitudes were lower in patients than in controls, while adult CMT1A patients and controls had a similar decline of strength and of CMAP amplitudes over time, suggesting that progression in patients may reflect a process of normal ageing. Physical disability however increased over time in the patient group and not in the control group. This may be explained by fewer reserves in patients, as baseline strength and CMAP amplitudes were lower. Also skeletal deformations may progress. Studies about the natural history in children are ongoing. Life expectancy is normal.

\section{Unresolved questions}

Why an increase or decrease in PMP22 gene copy number results in CMT1A or HNPP is still unknown. PMP22, also known as growth arrested specific gene 3 
(GAS3), is a transmembrane protein and its expression increases upon growth arrest [121] and in proliferating cells the levels are very low. The highest expression of PMP22 is detected in the Schwann cells of compact myelin. It is possible, that in these cells PMP22 serves another function. There is no unifying hypothesis how a PMP22 copy number variation or mutation leads to disease. In case of point mutations a toxic effect of misfolded protein is suggested, but this does not hold for the duplication and deletion of a normal copy of PMP22. In that case one can speculate that PMP22 interacts with other myelin components and stoichiometry is essential for proper function. However, there is no experimental data for this hypothesis.

The variability of the CMT1A phenotype, even within families [27], suggests the presence of modifiers - genetic and/or external factors - but these have not been identified thus far. We expect that part of the variation of the phenotype is due to genetic factors. Severely affected "double trouble" cases (the presence of two mutations in two different CMT-related genes) are reported [58,59] and show that known CMT genes can act as modifiers. Systematic screening of CMT genes in large cohorts of patients is necessary to identify the more common variants that affect the phenotype. With targeted NGS or whole exome sequencing [122] probably becoming the standard in DNA diagnostics in the near future, it is expected that variants in CMT related genes will be identified, which, together with a pathogenic mutation, determine the phenotypic expression of CMT in an individual patient. Thus far, the number of reports on these double trouble cases is low. We recommend that DNA screening of other CMT genes is performed in severely affected patients carrying a PMP22 duplication.

Variation in pathways involved in the immune system and its effect on nerve degeneration or regeneration may also affect the severity of the CMT phenotype. Analysis of transgenic models for CMT have excluded a role for $\mathrm{B}$ - and T-cells in the PMP22 overexpressing mice [123]. However, alterations in the innate immune system can affect the severity of the neuropathy. Heterozygous deletion of monocyte chemoattractant protein-1 (MCP-1) does affect axonal properties [124] and it was shown that inhibition of the complement system has a major effect on nerve degeneration and regeneration $[125,126]$.

Therapy for CMT1A thus far consists of supportive care only. Since the CMT1A phenotype is shown to result from a gene dosage effect [17-19], it is hypothesized that regulating the PMP22 gene dosage may be a therapeutic target. Two compounds that have been found to regulate PMP22 mRNA levels in rodent models are progesterone $[127,128]$ and ascorbic acid [129]. Ascorbic acid did not show a beneficial effect in several randomised controlled trials [130-134]. Onapristone, a progesterone receptor antagonist, reduced PMP22 mRNA levels and improved the phenotype in rodents [127]. However, clinical trials were not initiated due to the known serious side effects in humans [135]. No reports about progesterone antagonist treatment in CMT have been published since.

A pilot study undertaken by Sahenk et al. [136] showed that neurotrophin-3 (NT-3) improved the phenotype of the Trembler-J mouse and also led to slight improvement of sensory and reflex scores in CMT1A patients. Sahenk and colleagues proposed NT-3 treatment via adeno-associated virus (AAV) delivery to muscle and they showed in the Trembler-J mouse model that rAAV1. NT-3 therapy resulted in measurable NT-3 secretion levels in blood and improvement in motor function, histopathology, and electrophysiology of the peripheral nerves [137].

Cell line assays for high-throughput screens are a valuable new tool to select candidates from large numbers of existing compounds. Regulatory elements in the PMP22 gene are found that direct expression of PMP22 $[138,139]$. An intronic regulatory element was coupled to the luciferase gene, creating a high-throughput screen platform [140]. A multitude of compounds were tested on this assay, resulting in the identification of four compounds that decreased PMP22 mRNA and protein [140]. Follow-up assays followed by animal trials are the next step.

Two transgenic rodent models, the C3-PMP mice and the CMT-rat closely resemble human CMT1A and may be appropriate models for therapeutic studies $[79,141]$.

An important issue in developing treatment with drugs that showed benefit in animal studies is when to proceed to trials in patients. It can be argued that positive results in animal studies should be replicated first, before clinical trials in patients are developed [142].

Effective drug treatment may be directed at normalization of the myelination process, although improvement of the axonal function should be the ultimate goal. In view of this, therapies modulating the innate immune response should not be neglected. Since axonal degeneration already starts in childhood, drug treatment beginning early in life is expected to be most beneficial.

\section{PMP22 deletion - Hereditary Neuropathy with liability to Pressure Palsies (HNPP)}

Disease name

Hereditary Neuropathy with liability to Pressure Palsies (HNPP). Synonymes: tomaculous neuropathy. Polyneuropathy, familial recurrent. Orphanumber ORPHA640.

\section{Definition}

A deletion of the $1.5 \mathrm{Mb}$ region on chromosome $17 \mathrm{p} 11.2$, the same region that is duplicated in CMT1A 
[143] causes the autosomal dominantly inherited disorder Hereditary Neuropathy with liability to Pressure Palsies (HNPP). HNPP is an episodic, multifocal neuropathy. The typical clinical presentation is that of recurrent transient pressure palsies without pain, but with focal motor and sensory symptoms in the territory of a single nerve or the brachial plexus [144].

\section{Epidemiology}

The prevalence of HNPP is not well known [37]. Prevalences of 7.3 per 100,000 [23] to 16 per 100,000 [145] are reported.

\section{Clinical description}

HNPP typically leads to episodic, painless, recurrent, focal motor and sensory peripheral neuropathy [33]. It may cause attacks of numbness, muscular weakness, and atrophy [146]. Many episodes are preceded by minor compression on the affected nerve [146], for instance prolonged positioning of the limb. The most vulnerable nerves are the peroneal and ulnar nerves (30-48\% and $21-28 \%$, respectively), followed by the brachial plexus (12-27\%), radial nerve (4-13\%) and median nerve (4-11\%) $[144,147,148]$.

Age at onset of first HNPP symptoms is mostly in the second or third decade, with a large range from birth (although only two cases are described, one with an transient Erb's paresis [145] and one with neuropathy of the peroneal nerve and pes cavus [149]) to the eighth decade $[144,145,148,150-153]$. Most patients (60-70\%) present with a single, focal, acute neuropathy $[144,148,150]$. Cranial nerves are affected rarely [154]. Transient palsies of the facial [155-157], trigeminal $[155,158]$, hypoglossal $[155,159]$ and recurrent nerve [160] have been described. Although not being a typical transient nerve palsy, sensorineural hearing impairment of postnatal onset with progression beyond presbyacusis has been reported [46]. Other uncommon presentations include recurrent short-term positional sensory symptoms, progressive sensorimotor mononeuropathy of the peroneal nerve, chronic sensory polyneuropathy, chronic sensorimotor polyneuropathy and subacute peripheral quadriparetic episodes (initial diagnosis was chronic idiopathic demyelinating polyneuropathy) [144]. Also a Davidenkow phenotype (scapuloperoneal syndrome) is described [161].

On clinical examination, besides muscle weakness, atrophy and/or sensory signs in the affected nerves, reduced or absent tendon reflexes, mostly the ankle jerks, can be noted $[144,154]$. Pes cavus may be found in 4-47\% [144,148,150-152,157]. The symptoms from acute neuropathy usually disappear in days to weeks [146]. Full recovery occurs in $50 \%$ of episodes. Remaining symptoms are rarely severe [162]. Chronic motor deficits after nerve palsies are noted in $10 \%$ to $15 \%$ [144,148,150]. Other chronic symptoms like cramps, paresthesias and exercise-induced myalgia have been described [150].

There is large clinical variability between HNPP patients. At the mild end of the spectrum, patients can be clinically asymptomatic. In different studies the percentages of asymptomatic family members of index patients varied from $6 \%$ to $23 \%[144,148,150,152,153]$. At the severe end of the spectrum patients have residual symptoms after nerve palsies, which can mimic a CMT phenotype [146,163].

Electrophysiological studies show a characteristic pattern [144,147,164-167]. Essentially all HNPP patients, whether symptomatic or not [164] show an increase in distal motor latencies, especially of the median and peroneal nerves [166]. Most patients show focal motor slowing at entrapment sites, more commonly in the ulnar nerve at the elbow than in the peroneal nerve at the fibular head $[144,147,164,166]$. In other segments, $\mathrm{MCV}$ is normal in most cases, but can be slightly reduced in some. Sensory nerve conduction velocities are often decreased and sensory nerve action potential amplitudes are often reduced [166,167].

Nerve biopsy shows segmental de- and remyelination and varying large-fibre loss [168]. Tomacula, which are massive redundancies or overfolding of layers of variable thickness in the myelin sheath, are the pathologic hallmark [33], but are not pathognomonic.

Central nervous system white matter lesions have been reported in isolated patients and in several members of a large family with HNPP [169-171]. A recent report on 15 HNPP patients described central nervous system involvement [60]. Decreased white matter volume was found in $71 \%$, with minimal, predominantly executive, cognitive disorders in $64 \%$.

An overview of the key features of HNPP is presented in Table 1.

\section{Aetiology}

A $1.5 \mathrm{Mb}$ deletion on chromosome 17p11.2 [143,154] is found in approximately $85-90 \%$ of patients with clinical evidence of HNPP. Most of the CMT1A- or HNPPassociated rearrangements in $17 \mathrm{p} 11.2$ are recurrent and mediated by nonallelic homologous recombination, although rare cases of HNPP have deletions of different size but always including the PMP22 gene [68]. HNPP is an autosomal dominant disease. The de novo rate is probably 20\% [164]. Rare cases have mutations in the PMP22 gene. These mutations often result in stop codons and thus give rise to a null allele [172].

The gene dosage hypothesis is supported by the finding of decreased PMP22 protein [71] and decreased PMP22 mRNA expression levels in HNPP patients [173] that correlated with phenotype [174]. It is hypothesized that the focal symptoms of HNPP are caused by 
reversible conduction block (defined by $>50 \%$ reduction of CMAP amplitudes between distal and proximal sites of stimulation) [152]. Structural abnormalities at the node of Ranvier explain the changes in axonal excitability, and these abnormalities would predispose the nerves to conduction block when subjected to pressure or stretch [175]. In a mouse model heterozygous for Pmp22, conduction block was more rapidly induced by mechanical compression on the nerve in comparison to normal nerves [176] and recovery was slower. They found focal axonal constrictions within tomacula. Reduced axonal diameter raises resistance to action potential propagation and thus predisposes these axons to conduction block. When the nerve is compressed, it may cause even further thinning of axons.

\section{Diagnosis (diagnostic criteria and algorithms) and diagnostic methods}

Guidelines for diagnosis of HNPP are proposed by Dubourg et al. [154]. A clinical manifestation of acute, painless, recurrent peripheral nerve palsies is typical for HNPP. However, also with more uncommon presentations (see "clinical description") HNPP should be considered. A family history consistent with autosomal dominant inheritance is often present, but is not a prerequisite considering the de novo rate of $20 \%$ and asymptomatic occurrence of the disease. Electrophysiology of HNPP patients helps in establishing the diagnosis. Sonography of nerves show nerve hypertrophy at entrapment sites $[177,178]$, although not always significant [52].

If HNPP is suspected, DNA testing for the deletion of the PMP22 gene, followed by sequencing of the PMP22 gene if no deletion is found, can confirm the diagnosis. Like in CMT1A, nerve biopsy is essentially obsolete.

\section{Differential diagnosis}

Pressure palsies are commonly the result of acquired physical compression of peripheral nerves, mostly of the median nerve at the wrist (carpal tunnel syndrome), the peroneal nerve at the fibular head and the ulnar nerve at the elbow [162]. Screening for HNPP in 50 patients with isolated carpal tunnel syndrome showed that none of the patients had the PMP22 deletion [179]. The suspicion of HNPP should be higher if a patient suffers from more than one episode of compression neuropathy, if there is also an unexplained polyneuropathy present and if there is a family history of neuropathy [162]. Mononeuropathies may also be caused by compression due to a tumour, bleeding or abscess. In case of a neuropathy of the brachial plexus with a positive family history hereditary neuralgic amyotrophy (HNA) is considered most commonly $[146,163]$ and can be associated with mutations in the SEPT9 gene [180]. The nerve palsy in HNPP is painless, whereas the brachial plexopathy in HNA is preceded by severe pain. In case of a negative family history the sporadic form of HNA, idiopathic neuralgic amyotrophy, should be considered [163].

\section{Genetic counselling and antenatal diagnosis}

HNPP is an autosomal dominantly inherited disorder. For general aspects see corresponding paragraphs in the CMT1A section. In our experience, predictive testing, prenatal testing and PGD are not commonly requested.

\section{Management including treatment}

Treatment is currently symptomatic. Management during a pressure palsy may include transient bracing. If a pressure palsy is not transient but residual, the bracing may need to be permanent. Patients should be informed about avoiding activities that are risk factors for pressure palsies. These activities include prolonged sitting with legs crossed, occupations requiring repetitive movements of the wrist, prolonged leaning on elbows and rapid weight loss $[162,181]$. Toxin or medication-induced worsening of pre-existing peripheral neuropathy is a generally known phenomenon [115]. Vincristine, used in chemotherapy, has been reported to exacerbate HNPP [182]. No systematic controlled study of surgical decompression of nerves has been done. Given the vulnerability of the peripheral nerves in patients with HNPP, surgery is generally considered unfavourable [146].

Perspectives on future therapeutic developments are discussed in the "unresolved questions" section.

\section{Prognosis}

No natural history studies of HNPP exist. The prognosis is therefore unsure. In a study addressing age associated changes in electrophysiology [152], a reduction in CMAP with increasing age at examination was observed in nerves vulnerable to entrapment. This nerve-specific CMAP reduction likely results from a history of repetitive focal compression of the nerve. It is however not mentioned how the CMAP reduction correlates with symptoms. Recovery from acute neuropathy is often complete, although it can take months and if chronic symptoms persist, they are usually mild. Residual symptoms after nerve palsies can resemble a CMT phenotype [146,163]. Symptomatic individuals have the frustration and disability associated with recurrent pressure palsies [162]. Life expectancy is normal.

\section{Unresolved questions}

As for CMT1A, the phenotype is highly variable in HNPP, suggesting the presence of modifiers - genetic and/or external factors. So far none are identified.

Treatment is still only symptomatic. To our knowledge no trials have been undertaken. As HNPP is caused by a 
decreased dosage of $P M P 22$, increasing the gene dosage may be a therapeutic target, as decreasing the gene dosage is for CMT1A [146]. Stimulation of the endogenous $P M P 22$ by enhancing the regulatory elements of PMP22 might be one option. Another option is to introduce another copy of the PMP22 gene into the peripheral nerve by gene therapy. An obstacle is that increasing the dosage of PMP22 above a certain level will cause CMT1A.

\section{PMP22 point mutations}

Point mutations in PMP22 are found in a minority of patients suspected to have CMT or HNPP and the phenotype may vary from mild HNPP to severe CMT1 $[183,184]$. Clinical overlap between CMT1 and HNPP is also described, for instance in patients with the frameshift mutation Gly94fsX222 (c.281_282insG) [148,185]. For all general issues considering CMT1A and HNPP, see previous sections.

According to some classifications CMT caused by PMP22 mutations is also called CMT1A [7], while others consider this a separate disease entity called CMT1E $[99,184,186]$. One could argue to classify CMT caused by PMP22 point mutations as a separate entity, because the genetic defect is different from CMT caused by PMP22 duplication. An extra argument for considering this a separate disease entity is that $P M P 22$ point mutations can phenotypically lead to CMT as well as HNPP or even an overlap between the two phenotypes. In this perspective, HNPP due to PMP22 point mutations should also be seen as a separate entity from HNPP due to PMP22 deletion.

Several types of $P M P 22$ point mutations are described (missense, nonsense, frameshift and splice-site mutations [5]). Controversy about the pathogenicity of the Thr118Met mutation exists. It is reported as a benign polymorphism, as an autosomal recessive inherited mutation or as an autosomal dominant mutation, with HNPP as phenotype [187]. Very rare autosomal recessive neuropathy (CMT4), caused by homozygosity for point mutations in PMP22 $[188,189]$ has been reported.

\section{Conclusions}

PMP22 related neuropathies are the most prevalent amongst the inherited neuropathies. Knowledge about clinical presentation of CMT1A and HNPP and the expanding possibilities of genetic testing is a prerequisite for all neurologists and geneticists dealing with inherited neuropathy patients. Research on therapy has so far largely focussed on CMT1A, because of its prevalence and the rationale of decreasing the gene dosage of PMP22 which could potentially reverse the phenotype. One should keep in mind that a PMP22 directed therapy can not be applied to all cases of CMT. Therefore the genetic subtyping of CMT is essential to select those cases that might be eligible for targeted treatment strategies, as soon as these treatments become available.

\section{Abbreviations}

AD: Autosomal dominant; AR: Autosomal recessive; ARHGEF10: Rho guanine nucleotide exchange factor 10; CIDP: Chronic inflammatory demyelinating polyneuropathy; CMAP: Compound muscle action potential; CMT: CharcotMarie-Tooth disease; CMT1: Charcot-Marie-Tooth disease type 1; CMT1A: Charcot-Marie-Tooth disease type 1A; CSA: Cross-sectional area; CTDP1: C-terminal domain of RNA polymerase II subunit A, phosphatase, subunit 1; DNA: Deoxyribonucleic acid; EGR2: Early growth response 2; FBLN5: Fibulin 5; FGD4: FYVE, RhoGEF and PH domain-containing protein 4; FIG4: FIG4 homolog of S. cerevisiae; GDAP1: Ganglioside-induced differentiation-associated protein 1; GJB1: Gap junction protein, beta 1; HK1: Hexokinase 1; HMSN la: Hereditary motor and sensory neuropathy type la; HMSN: Hereditary motor and sensory neuropathy; HNA: Hereditary neuralgic amyotrophy; HNPP: Hereditary neuropathy with liability to pressure palsies; LITAF: Lipopolysaccharide-induced tumor necrosis factor-alpha factor; Mb: Mega base pairs; MCV: Motor conduction velocity; MPZ: Myelin protein zero; MTMR2: Myotubularin-related protein 2; NDRG1: N-myc downstreamregulated gene 1; NEFL: Neurofilament protein, light polypeptide; NGS: Next generation sequencing; PGD: Pre-implantation genetic diagnosis; PMP22: Peripheral myelin protein 22; PRX: Periaxin; RNA: Ribonucleic acid; SBF1: SET-binding factor 1; SBF2: SET-binding factor 2; SH3TC2: SH3 domain and tetratricopeptide repeat domain 2; SNAP: Sensory nerve action potential; SURF1: Surfeit 1; WES: Whole exome sequencing.

\section{Competing interests}

The authors declare that they have no competing interests.

\section{Authors' contributions}

BWvP: drafting of the manuscript. AJvdK: revising of the manuscript. KvS-Z: revising of the manuscript. CV: drafting the parts on electrophysiology and revising of the manuscript. FB: revising of the manuscript. MdV: initiator and revising of the manuscript. All authors read and approved the final manuscript.

\section{Acknowledgements}

BWVP is supported by a grant (WAR08-18) of the Prinses Beatrix Fonds, The Hague.

\section{Author details}

'Department of Clinical Genetics, Academic Medical Center, Meibergdreef 9, 1105 AZ, Amsterdam, the Netherlands. ${ }^{2}$ Department of Neurology, Academic Medical Center, Meibergdreef 9, 1105 AZ, Amsterdam, the Netherlands.

${ }^{3}$ Department of Genome Analysis, Academic Medical Center, Meibergdreef 9, 1105 AZ, Amsterdam, the Netherlands.

Received: 29 September 2013 Accepted: 6 March 2014

Published: 19 March 2014

\section{References}

1. Dyck PJ, Lambert EH: Lower motor and primary sensory neuron diseases with peroneal muscular atrophy. I. Neurologic, genetic, and electrophysiologic findings in hereditary polyneuropathies. Arch Neurol 1968, 18:603-618.

2. Charcot JM, Marie P: Sur une forme particulière d'atrophie musculaire progressive, souvent familial, débutant par les pieds et les jambes et atteignant plus tard les mains. Rev Méd Paris 1886, 6:97-138.

3. Tooth HH: The peroneal type of progressive muscular atrophy. London: Lewis HK; 1886.

4. Neuromuscular Home Page. http://neuromuscular.wustl.edu/time/hmsn.html.

5. Inherited Peripheral Neuropathies Mutation Database. http://www. molgen.ua.ac.be/cmtmutations/Mutations/Default.cfm.

6. Pareyson D, Scaioli V, Laura M: Clinical and electrophysiological aspects of Charcot-Marie-Tooth disease. Neuromolecular Med 2006, 8:3-22.

7. Reilly MM: Sorting out the inherited neuropathies. Pract Neurol 2007, 7:93-105.

8. Harding AE, Thomas PK: The clinical features of hereditary motor and sensory neuropathy types I and II. Brain 1980, 103:259-280.

9. Nicholson G, Myers S: Intermediate forms of Charcot-Marie-Tooth neuropathy: a review. Neuromolecular Med 2006, 8:123-130.

10. Davis CJ, Bradley WG, Madrid R: The peroneal muscular atrophy syndrome: clinical, genetic, electrophysiological and nerve biopsy studies. I. Clinical, genetic and electrophysiological findings and classification. J Genet Hum 1978, 26:311-349. 
11. Rossi A, Paradiso C, Cioni R, Rizzuto N, Guazzi G: Charcot-Marie-Tooth disease: study of a large kinship with an intermediate form. $J$ Neurol 1985, 232:91-98

12. Madrid R, Bradley WG, Davis CJ: The peroneal muscular atrophy syndrome. Clinical, genetic, electrophysiological and nerve biopsy studies. Part 2. Observations on pathological changes in sural nerve biopsies. J Neurol Sci 1977, 32:91-122.

13. Rouger H, LeGuern E, Birouk N, Gouider R, Tardieu S, Plassart E, Gugenheim M, Vallat JM, Louboutin JP, Bouche P, Agid Y, Brice A: Charcot-Marie-Tooth disease with intermediate motor nerve conduction velocities: characterization of 14 Cx32 mutations in 35 families. Hum Mutat 1997, 10:443-452.

14. Gabreels-Festen AA, Gabreels FJ, Jennekens FG: Hereditary motor and sensory neuropathies. Present status of types I, II and III. Clin Neurol Neurosurg 1993, 95:93-107.

15. Raeymaekers P, Timmerman V, Nelis E, De Jonghe P, Hoogendijk JE, Baas F, Barker DF, Martin JJ, De Visser M, Bolhuis PA: Duplication in chromosome 17p11.2 in Charcot-Marie-Tooth neuropathy type 1a (CMT 1a). The HMSN Collaborative Research Group. Neuromuscul Disord 1991, 1:93-97.

16. Lupski JR, De Oca-Luna RM, Slaugenhaupt S, Pentao L, Guzzetta V, Trask BJ, Saucedo-Cardenas O, Barker DF, Killian JM, Garcia CA, Chakravarti A, Patel PI: DNA duplication associated with Charcot-Marie-Tooth disease type 1A. Cell 1991, 66:219-232.

17. Patel PI, Roa BB, Welcher AA, Schoener-Scott R, Trask BJ, Pentao L, Snipes GJ, Garcia CA, Francke U, Shooter EM, Lupski JR, Suter U: The gene for the peripheral myelin protein PMP-22 is a candidate for Charcot-Marie-Tooth disease type 1A. Nat Genet 1992, 1:159-165.

18. Timmerman V, Nelis E, Van Hul W, Nieuwenhuijsen BW, Chen KL, Wang S, Ben Othman K, Cullen B, Leach RJ, Hanemann CO, De Jonghe $P$, Raeymaekers P, Van Ommen GJB, Martin JJ, Müller HW, Vance JM, Fischbeck $\mathrm{KH}$, Van Broeckhoven C: The peripheral myelin protein gene PMP-22 is contained within the Charcot-Marie-Tooth disease type 1A duplication [published erratum appears in Nat Genet 1992 Sep;2(1):84]. Nat Genet 1992, 1:171-175.

19. Valentijn $L$, Bolhuis PA, Zorn I, Hoogendijk JE, van den Bosch N, Hensels GW, Stanton VP Jr, Housman DE, Fischbeck KH, Ross DA, Nicholson GA, Meershoek EJ, Dauwerse HG, Van Ommen GJB, Baas F: The peripheral myelin gene PMP-22/GAS-3 is duplicated in Charcot- Marie-Tooth disease type 1A. Nat Genet 1992, 1:166-170.

20. Matsunami N, Smith B, Ballard L, Lensch MW, Robertson M, Albertsen H, Hanemann CO, Muller HW, Bird TD, White R, Chance PF: Peripheral myelin protein-22 gene maps in the duplication in chromosome 17p11.2 associated with Charcot-Marie-Tooth 1A. Nat Genet 1992, 1:176-179.

21. Skre H: Genetic and clinical aspects of Charcot-Marie-Tooth's disease. Clin Genet 1974, 6:98-118.

22. Braathen GJ, Sand JC, Lobato A, Hoyer H, Russell MB: Genetic epidemiology of Charcot-Marie-Tooth in the general population. Eur J Neurol 2011, 18:39-48.

23. Foley C, Schofield I, Eglon G, Bailey G, Chinnery PF, Horvath R: CharcotMarie-Tooth disease in Northern England. I Neurol Neurosurg Psychiatry 2012, 83:572-573.

24. Nicolaou P, Zamba-Papanicolaou E, Koutsou P, Kleopa KA, Georghiou A, Hadjigeorgiou G, Papadimitriou A, Kyriakides T, Christodoulou K: CharcotMarie-Tooth disease in Cyprus: epidemiological, clinical and genetic characteristics. Neuroepidemiology 2010, 35:171-177.

25. Karadima G, Floroskufi P, Koutsis G, Vassilopoulos D, Panas M: Mutational analysis of PMP22, GJB1 and MPZ in Greek Charcot-Marie-Tooth type 1 neuropathy patients. Clin Genet 2011, 80:497-499.

26. Thomas PK, Marques W Jr, Davis MB, Sweeney MG, King RH, Bradley $J$, Muddle JR, Tyson J, Malcolm S, Harding AE: The phenotypic manifestations of chromosome 17p11.2 duplication. Brain 1997, 120(3):465-478.

27. Birouk N, Gouider R, Le Guern E, Gugenheim M, Tardieu S, Maisonobe T, Le Forestier N, Agid Y, Brice A, Bouche P: Charcot-Marie-Tooth disease type $1 \mathrm{~A}$ with $17 \mathrm{p} 11.2$ duplication. Clinical and electrophysiological phenotype study and factors influencing disease severity in 119 cases. Brain 1997, 120:813-823.

28. Marques W Jr, Freitas MR, Nascimento OJ, Oliveira AB, Calia L, Melo A Lucena R, Rocha V, Barreira AA: 17p duplicated Charcot-Marie-Tooth 1A Characteristics of a new population. J Neurol 2005, 252:972-979.

29. Bienfait HM, Verhamme C, Van Schaik IN, Koelman JH, De Visser BW, De Haan RJ, Baas F, Van Engelen BG, De Visser M: Comparison of CMT1A and CMT2: similarities and differences. J Neurol 2006, 253:1572-1580.
30. Berciano J, Garcia A, Combarros O: Initial semeiology in children with Charcot-Marie-Tooth disease 1A duplication. Muscle Nerve 2003, 27:34-39.

31. Baets J, Deconinck T, De Vriendt E, Zimon M, Yperzeele L, Van Hoorenbeeck K, Peeters K, Spiegel R, Parman Y, Ceulemans B, Van Bogaert P, Pou-Serradell A, Bernea G, Dinopoulos A, Auer-Grumbach M, Sallinen SL, Fabrizi GM, Pauly F, Van den Bergh P, Bilir B, Battaloglu E, Madrid RE, Kabzinska D, Kochanski A, Topaloglu H, Miller G, Jordanova A, Timmerman V, De Jonghe P: Genetic spectrum of hereditary neuropathies with onset in the first year of life. Brain 2011, 134:2664-2676.

32. Abe Y, Ikegami T, Hayasaka K, Tanno Y, Watanabe T, Sugiyama Y, Yamamoto T: Pressure palsy as the initial presentation in a case of late-onset Charcot-Marie-Tooth disease type 1A. Intern Med 1997, 36:501-503.

33. Lupski JR, Chance PF: Hereditary Motor and Sensory Neuropathies Involving Altered Dosage or Mutation of PMP22: The CMT1A Duplication and HNPP Deletion. In Peripheral Neuropathy. Fourthth edition. Edited by Dyck PJ, Thomas PK. Philadelphia: Elsevier Saunders; 2005:1659-1680.

34. Hoogendijk JE, De Visser M, Bolhuis PA, Hart AA, Ongerboer de Visser BW: Hereditary motor and sensory neuropathy type I: clinical and neurographical features of the 17p duplication subtype. Muscle Nerve 1994, 17:85-90.

35. Verhamme C, Van Schaik IN, Koelman JHTM, De Haan RJ, De Visser M: The natural history of Charcot-Marie-Tooth type 1A in adults: a 5-year follow-up study. Brain 2009, 132:3252-3262.

36. Videler AJ, Beelen A, Van Schaik IN, De Visser M, Nollet F: Manual dexterity in hereditary motor and sensory neuropathy type 1a: severity of limitations and feasibility and reliability of two assessment instruments. J Rehabil Med 2008, 40:132-136.

37. Shy ME, Lupski JR, Chance PF, Klein CJ, Dyck PJ: Hereditary Motor and Sensory Neuropathies: An overview of Clinical, Genetic, Electrophysiologic, and Pathologic Features. In Peripheral Neuropathy. Fourthth edition. Edited by Dyck PJ, Thomas PK. Philadelphia: Elsevier Saunders; 2005:1623-1658.

38. Verhamme C, Van Schaik IN, Koelman JHTM, De Haan RJ, Vermeulen M, De Visser M: Clinical disease severity and axonal dysfunction in hereditary motor and sensory neuropathy la. J Neurol 2004, 251:1491-1497.

39. Ribiere C, Bernardin M, Sacconi S, Delmont E, Fournier-Mehouas M, Rauscent H, Benchortane M, Staccini P, Lanteri-Minet M, Desnuelle C: Pain assessment in Charcot-Marie-Tooth (CMT) disease. Ann Phys Rehabil Med 2012, 55:160-173.

40. Gemignani F, Melli G, Alfieri S, Inglese C, Marbini A: Sensory manifestations in Charcot-Marie-Tooth disease. J Peripher Nerv Syst 2004, 9:7-14.

41. Kalkman JS, Schillings ML, van der Werf SP, Padberg GW, Zwarts MJ, Van Engelen BG, Bleijenberg G: Experienced fatigue in facioscapulohumeral dystrophy, myotonic dystrophy, and HMSN-I. J Neurol Neurosurg Psychiatry 2005, 76:1406-1409.

42. Jagersma E, Jeukens-Visser M, Van Paassen BW, Meester-Delver A, Nollet F: Severe Fatigue and Reduced Quality of Life in Children With Hereditary Motor and Sensory Neuropathy 1A. J Child Neurol 2013, 28:429-434.

43. Auer-Grumbach M, Strasser-Fuchs S, Wagner K, Korner E, Fazekas F: RoussyLevy syndrome is a phenotypic variant of Charcot-Marie-Tooth syndrome IA associated with a duplication on chromosome 17p11.2. J Neuro/ Sci 1998, 154:72-75.

44. Carvalho AA, Vital A, Ferrer X, Latour P, Lagueny A, Brechenmacher C, Vital C: Charcot-Marie-Tooth disease type 1A: clinicopathological correlations in 24 patients. J Peripher Nerv Syst 2005, 10:85-92.

45. Plante-Bordeneuve V, Guiochon-Mantel A, Lacroix C, Lapresle J, Said G: The Roussy-Levy family: from the original description to the gene. Ann Neurol 1999, 46:770-773.

46. Verhagen Wl, Huygen PL, Gabreels-Festen AA, Engelhart M, Van Mierlo PJ, Van Engelen BG: Sensorineural hearing impairment in patients with Pmp22 duplication, deletion, and frameshift mutations. Otol Neurotol 2005, 26:405-414.

47. Rance G, Ryan MM, Bayliss K, Gill K, O'Sullivan C, Whitechurch M: Auditory function in children with Charcot-Marie-Tooth disease. Brain 2012, 135:1412-1422.

48. Poretti A, Palla A, Tarnutzer AA, Petersen JA, Weber KP, Straumann D, Jung $\mathrm{HH}$ : Vestibular impairment in patients with Charcot-Marie-tooth disease. Neurology 2013, 80:2099-2105.

49. Boentert M, Knop K, Schuhmacher C, Gess B, Okegwo A, Young P: Sleep disorders in Charcot-Marie-Tooth disease type 1. J Neurol Neurosurg Psychiatry 2014, 85:319-325.

50. Martinoli C, Schenone A, Bianchi S, Mandich P, Caponetto C, Abbruzzese M, Derchi LE: Sonography of the median nerve in Charcot-Marie-Tooth disease. AJR Am J Roentgenol 2002, 178:1553-1556. 
51. Sinclair CD, Miranda MA, Cowley P, Morrow JM, Davagnanam I, Mehta H, Hanna MG, Koltzenburg M, Reilly MM, Yousry TA, Thornton JS: MRI shows increased sciatic nerve cross sectional area in inherited and inflammatory neuropathies. J Neurol Neurosurg Psychiatry 2011, 82:1283-1286.

52. Schreiber S, Oldag A, Kornblum C, Kollewe K, Kropf S, Schoenfeld A, Feistner H, Jakubiczka S, Kunz WS, Scherlach C, Tempelmann C, Mawrin C, Dengler R, Schreiber F, Goertler M, Vielhaber S: Sonography of the median nerve in CMT1A, CMT2A, CMTX, and HNPP. Muscle Nerve 2013, 47:385-395.

53. Zaidman CM, Al-Lozi M, Pestronk A: Peripheral nerve size in normals and patients with polyneuropathy: an ultrasound study. Muscle Nerve 2009, 40:960-966.

54. Kaku DA, Parry GJ, Malamut R, Lupski JR, Garcia CA: Nerve conduction studies in Charcot-Marie-Tooth polyneuropathy associated with a segmental duplication of chromosome 17. Neurology 1806-1808, 1993:43.

55. Garcia CA, Malamut RE, England JD, Parry GS, Liu P, Lupski JR: Clinical variability in two pairs of identical twins with the Charcot-Marie-Tooth disease type 1A duplication. Neurology 2090-2093, 1995:45.

56. Silander K, Meretoja P, Nelis E, Timmerman V, Van Broeckhoven C, Aula P, Savontaus ML: A de novo duplication in 17p11.2 and a novel mutation in the Po gene in two Dejerine-Sottas syndrome patients. Hum Mutat 1996, 8:304-310.

57. Plante-Bordeneuve V, Parman Y, Guiochon-Mantel A, Alj Y, Deymeer F, Serdaroglu P, Eraksoy M, Said G: The range of chronic demyelinating neuropathy of infancy: a clinico- pathological and genetic study of 15 unrelated cases. J Neurol 2001, 248:795-803.

58. Meggouh F, De Visser M, Arts WF, De Coo RI, Van Schaik IN, Baas F: Early onset neuropathy in a compound form of Charcot-Marie-Tooth disease. Ann Neurol 2005, 57:589-591.

59. Hodapp JA, Carter GT, Lipe HP, Michelson SJ, Kraft GH, Bird TD: Double trouble in hereditary neuropathy: concomitant mutations in the PMP-22 gene and another gene produce novel phenotypes. Arch Neurol 2006, 63:112-117.

60. Chanson JB, Echaniz-Laguna A, Blanc F, Lacour A, Ballonzoli L, Kremer S, Namer IJ, Lannes B, Tranchant C, Vermersch P, De Seze J: Central nervous system abnormalities in patients with PMP22 gene mutations: a prospective study. J Neurol Neurosurg Psychiatry 2013, 84:392-397.

61. Uncini A, Di Guglielmo G, Di Muzio A, Gambi D, Sabatelli M, Mignogna T, Tonali P, Marzella R, Finelli P, Archidiacono N, Rocchi M: Differential electrophysiological features of neuropathies associated with $17 \mathrm{p} 11.2$ deletion and duplication. Muscle Nerve 1995, 18:628-635.

62. Lewis RA, Krajewski K, Tate B, Shy ME: Motor Unit Number Estimation (MUNE) of Proximal and Distal Extremity Muscles in CMT1A, CMTX, and CMT2. Neurology 2000, 54(Suppl 3):A70.

63. Gabreels-Festen AA, Bolhuis PA, Hoogendijk JE, Valentijn LJ, Eshuis EJ, Gabreels FJ: Charcot-Marie-Tooth disease type 1A: morphological phenotype of the $17 p$ duplication versus PMP22 point mutations. Acta Neuropathol 1995, 90:645-649.

64. Fabrizi GM, Simonati A, Morbin M, Cavallaro T, Taioli F, Benedetti MD, Edomi P, Rizzuto N: Clinical and pathological correlations in Charcot-Marie-Tooth neuropathy type $1 \mathrm{~A}$ with the $17 \mathrm{p} 11.2 \mathrm{p} 12$ duplication: a cross- sectional morphometric and immunohistochemical study in twenty cases. Muscle Nerve 1998, 21:869-877.

65. Gabreels-Festen AA, Joosten EM, Gabreels FJ, Jennekens FG, Janssen-van Kempen TW: Early morphological features in dominantly inherited demyelinating motor and sensory neuropathy (HMSN type I). J Neurol Sci 1992, 107:145-154.

66. Smith TW, Bhawan J, Keller RB, DeGirolami U: Charcot-Marie-Tooth disease associated with hypertrophic neuropathy: a neuropathologic study of two cases. J Neuropathol Exp Neurol 1980, 39:420-440.

67. Valentijn LJ, Baas F, Zorn I, Hensels GW, De Visser M, Bolhuis PA: Alternatively sized duplication in Charcot-Marie-Tooth disease type $1 \mathrm{~A}$. Hum Mol Genet 1993, 2:2143-2146.

68. Zhang F, Seeman P, Liu P, Weterman MA, Gonzaga-Jauregui C, Towne CF, Batish SD, De Vriendt E, De Jonghe P, Rautenstrauss B, Krause KH, Khajavi M, Posadka J, Vandenberghe A, Palau F, Van Maldergem L, Baas F, Timmerman $V$, Lupski JR: Mechanisms for nonrecurrent genomic rearrangements associated with CMT1A or HNPP: rare CNVs as a cause for missing heritability. Am J Hum Genet 2010, 86:892-903.

69. Weterman MA, Van Ruissen F, De Wissel M, Bordewijk L, Samijn JP, van der Pol WL, Meggouh F, Baas F: Copy number variation upstream of PMP22 in Charcot-Marie-Tooth disease. Eur J Hum Genet 2010, 18:421-428.
70. Valentijn $\amalg$, Baas F, Wolterman RA, Hoogendijk JE, van den Bosch NHA, Zorn I, Gabreëls-Festen AAWM, De Visser M, Bolhuis PA: Identical point mutations of PMP-22 in Trembler-J mouse and Charcot-Marie-Tooth disease type 1A. Nat Genet 1992, 2:288-291.

71. Gabriel JM, Erne B, Pareyson D, Sghirlanzoni A, Taroni F, Steck AJ: Gene dosage effects in hereditary peripheral neuropathy. Expression of peripheral myelin protein 22 in Charcot-Marie-Tooth disease type $1 \mathrm{~A}$ and hereditary neuropathy with liability to pressure palsies nerve biopsies. Neurology 1997, 49:1635-1640.

72. Yoshikawa H, Nishimura T, Nakatsuji Y, Fujimura H, Himoro M, Hayasaka K, Sakoda S, Yanagihara T: Elevated expression of messenger RNA for peripheral myelin protein 22 in biopsied peripheral nerves of patients with Charcot- Marie-Tooth disease type 1A. Ann Neurol 1994, 35:445-450

73. Snipes GJ, Suter U, Welcher AA, Shooter EM: Characterization of a novel peripheral nervous system myelin protein (PMP-22/SR13). J Cell Biol 1992, 117:225-238.

74. Krajewski KM, Lewis RA, Fuerst DR, Turansky C, Hinderer SR, Garbern J, Kamholz J, Shy ME: Neurological dysfunction and axonal degeneration in Charcot-Marie-Tooth disease type 1A. Brain 2000, 123:1516-1527.

75. Hattori N, Yamamoto M, Yoshihara T, Koike H, Nakagawa M, Yoshikawa H, Ohnishi A, Hayasaka K, Onodera O, Baba M, Yasuda H, Saito T, Nakashima K, Kira J, Kaji R, Oka N, Sobue G: Demyelinating and axonal features of Charcot-Marie-Tooth disease with mutations of myelin-related proteins (PMP22, MPZ and Cx32): a clinicopathological study of 205 Japanese patients. Brain 2003, 126:134-151.

76. Robaglia-Schlupp A, Pizant J, Norreel JC, Passage E, Saberan-Djoneidi D, Ansaldi JL, Vinay L, Figarella-Branger D, Levy N, Clarac F, Cau P, Pellissier JF, Fontés M: PMP22 overexpression causes dysmyelination in mice. Brain 2002, 125:2213-2221.

77. Yiu EM, Burns J, Ryan MM, Ouvrier RA: Neurophysiologic abnormalities in children with Charcot-Marie-Tooth disease type 1A. J Peripher Nerv Syst 2008, 13:236-241.

78. Saporta MA, Katona I, Lewis RA, Masse S, Shy ME, Li J: Shortened internodal length of dermal myelinated nerve fibres in Charcot-Marie-Tooth disease type 1A. Brain 2009, 132:3263-3273.

79. Verhamme C, King RH, Ten Asbroek AL, Muddle JR, Nourallah M, Wolterman R, Baas F, Van Schaik IN: Myelin and axon pathology in a long-term study of PMP22-overexpressing mice. J Neuropathol Exp Neurol 2011, 70:386-398.

80. Hoogendijk JE, Hensels GW, Gabreels-Festen AA, Gabreels FJ, Janssen EA, De Jonghe P, Martin JJ, Van Broeckhoven C, Valentijn L, Baas F, De Visser M, Bolhuis PA: De-novo mutation in hereditary motor and sensory neuropathy type I. Lancet 1992, 339:1081-1082.

81. Blair IP, Nash J, Gordon MJ, Nicholson GA: Prevalence and origin of de novo duplications in Charcot-Marie-Tooth disease type 1A: first report of a de novo duplication with a maternal origin. Am J Hum Genet 1996, 58:472-476

82. Timmerman V, Strickland A, Züchner S: Genetics of Charcot-Marie-Tooth (CMT) Disease within the Frame of the Human Genome Project Success. Genes 2014, 5:13-32.

83. Rossor AM, Polke JM, Houlden H, Reilly MM: Clinical implications of genetic advances in Charcot-Marie-Tooth disease. Nat Rev Neurol 2013, 9:562-571.

84. Azzedine H, Senderek J, Rivolta C, Chrast R: Molecular genetics of charcot-marie-tooth disease: from genes to genomes. Mol Syndromol 2012, 3:204-214

85. Gieselmann V, Krageloh-Mann I: Metachromatic leukodystrophy-an update. Neuropediatrics 2010, 41:1-6

86. Jansen GA, Waterham HR, Wanders RJ: Molecular basis of Refsum disease: sequence variations in phytanoyl-CoA hydroxylase (PHYH) and the PTS2 receptor (PEX7). Hum Mutat 2004, 23:209-218.

87. Siddiqi ZA, Sanders DB, Massey JM: Peripheral neuropathy in Krabbe disease: electrodiagnostic findings. Neurology 2006, 67:263-267.

88. Engelen M, Kemp S, De Visser M, Van Geel BM, Wanders RJ, Aubourg P, PollThe BT: X-linked adrenoleukodystrophy (X-ALD): clinical presentation and guidelines for diagnosis, follow-up and management. Orphanet J Rare Dis 2012, 7:51-64

89. Uhlenberg B, Schuelke M, Ruschendorf F, Ruf N, Kaindl AM, Henneke M, Thiele H, Stoltenburg-Didinger G, Aksu F, Topaloglu H, Nurnberg P, Hubner C, Weschke B, Gartner J: Mutations in the gene encoding gap junction protein alpha 12 (connexin 46.6) cause Pelizaeus-Merzbacher-like disease. Am J Hum Genet 2004, 75:251-260. 
90. Loi M: Lowe syndrome. Orphanet J Rare Dis 2006, 1:16-20.

91. Latov N: Biomarkers of CIDP in patients with diabetes or CMT1. J Peripher Nerv Syst 2011, 16(Suppl 1):14-17

92. Pareyson D: Differential diagnosis of Charcot-Marie-Tooth disease and related neuropathies. Neurol Sci 2004, 25:72-82.

93. Gabreels-Festen AA, Gabreels FJ, Hoogendijk JE, Bolhuis PA, Jongen PJ, Vingerhoets HM: Chronic inflammatory demyelinating polyneuropathy or hereditary motor and sensory neuropathy? Diagnostic value of morphological criteria. Acta Neuropathol 1993, 86:630-635.

94. Said G: Diabetic neuropathy-a review. Nat Clin Pract Neurol 2007, 3:331-340.

95. Said G, Bigo A, Ameri A, Gayno JP, Elgrably F, Chanson P, Slama G: Uncommon early-onset neuropathy in diabetic patients. J Neurol 1998 245:61-68.

96. Fusco C, Frattini D, Scarano A, Giustina ED: Congenital pes cavus in a Charcot-Marie-tooth disease type 1A newborn. Pediatr Neurol 2009, 40:461-464.

97. Steiner I, Gotkine M, Steiner-Birmanns B, Biran I, Silverstein S, Abeliovich D, Argov Z, Wirguin I: Increased severity over generations of Charcot-MarieTooth disease type 1A. J Neurol 2008, 255:813-819.

98. Dupre N, Bouchard JP, Cossette L, Brunet D, Vanasse M, Lemieux B, Mathon G, Puymirat J: Clinical and electrophysiological study in French-Canadian population with Charcot-Marie-tooth disease type $1 \mathrm{~A}$ associated with 17p11.2 duplication. Can J Neurol Sci 1999, 26:196-200.

99. Bird TD: Charcot-Marie-Tooth Neuropathy Type 1. In GeneReviews ${ }^{\text {TM }}$ [Internet]. Edited by Pagon RA, Adam MP, Bird TD. Seattle: University of Washington, Seattle; 1993:2014.

100. Borry P, Evers-Kiebooms G, Cornel MC, Clarke A, Dierickx K: Genetic testing in asymptomatic minors: background considerations towards ESHG Recommendations. Eur J Hum Genet 2009, 17:711-719.

101. American Society of Human Genetics Board of Directors, American College of Medical Genetics Board of Directors: Points to consider: ethical, legal, and psychosocial implications of genetic testing in children and adolescents. Am J Hum Genet 1995, 57:1233-1241.

102. Bernard R, Boyer A, Negre P, Malzac $P$, Latour P, Vandenberghe A, Philip N, Levy N: Prenatal detection of the 17p11.2 duplication in Charcot-MarieTooth disease type 1A: necessity of a multidisciplinary approach for heterogeneous disorders. Eur J Hum Genet 2002, 10:297-302.

103. Goossens V, Traeger-Synodinos J, Coonen E, De Rycke M, Moutou C, Pehlivan T, Derks-Smeets IA, Harton G: ESHRE PGD Consortium data collection XI: cycles from January to December 2008 with pregnancy follow-up to October 2009. Hum Reprod 1887-1911, 2012:27.

104. Harper JC, Wilton L, Traeger-Synodinos J, Goossens V, Moutou C, SenGupta SB, Pehlivan Budak T, Renwick P, De Rycke M, Geraedts JP, Harton G: The ESHRE PGD Consortium: 10 years of data collection. Hum Reprod Update 2012 18:234-247.

105. Young P, De Jonghe P, Stogbauer F, Butterfass-Bahloul T: Treatment for Charcot-Marie-Tooth disease. Cochrane Database Syst Rev 2008, 1:CD006052.

106. Sackley C, Disler PB, Turner-Stokes L, Wade DT, Brittle N, Hoppitt T: Rehabilitation interventions for foot drop in neuromuscular disease. Cochrane Database Syst Rev 2009, 3:CD003908

107. Guyton GP, Mann RA: The pathogenesis and surgical management of foot deformity in Charcot-Marie-Tooth disease. Foot Ankle Clin 2000, 5:317-326.

108. Ward CM, Dolan LA, Bennett DL, Morcuende JA, Cooper RR: Long-term results of reconstruction for treatment of a flexible cavovarus foot in Charcot-Marie-Tooth disease. J Bone Joint Surg Am 2008, 90:2631-2642.

109. Leeuwesteijn AE, De Visser E, Louwerens JW: Flexible cavovarus feet in Charcot-Marie-Tooth disease treated with first ray proximal dorsiflexion osteotomy combined with soft tissue surgery: a short-term to mid-term outcome study. Foot Ankle Surg 2010, 16:142-147.

110. Videler $A$, Eijffinger $E$, Nollet $F$, Beelen $A$ : $A$ thumb opposition splint to improve manual dexterity and upper-limb functioning in Charcot-MarieTooth disease. J Rehabil Med 2012, 44:249-253.

111. Wood VE, Huene D, Nguyen J: Treatment of the upper limb in CharcotMarie-Tooth disease. J Hand Surg [Br ] 1995, 20:511-518.

112. Brown RE, Zamboni WA, Zook EG, Russell RC: Evaluation and management of upper extremity neuropathies in Charcot- Marie-Tooth disease. J Hand Surg [Am ] 1992, 17:523-530.

113. Sheth S, Francies K, Siskind CE, Feely SM, Lewis RA, Shy ME: Diabetes mellitus exacerbates motor and sensory impairment in CMT1A. J Peripher Nerv Syst 2008, 13:299-304
114. Ursino G, Alberti MA, Grandis M, Reni L, Pareyson D, Bellone E, Gemelli C, Sabatelli M, Pisciotta C, Luigetti M, Santoro L, Massollo L, Schenone A: Influence of comorbidities on the phenotype of patients affected by Charcot-Marie-Tooth neuropathy type 1A. Neuromuscul Disord 2013, 23:902-906

115. Weimer LH, Podwall D: Medication-induced exacerbation of neuropathy in Charcot Marie Tooth disease. J Neurol Sci 2006, 242:47-54.

116. Graf WD, Chance PF, Lensch MW, Eng L, Lipe HP, Bird TD: Severe vincristine neuropathy in Charcot-Marie-Tooth disease type 1A. Cancer 1996, 77:1356-1362.

117. Hildebrandt G, Holler E, Woenkhaus M, Quarch G, Reichle A, Schalke B, Andreesen R: Acute deterioration of Charcot-Marie-Tooth disease IA (CMT IA) following $2 \mathrm{mg}$ of vincristine chemotherapy. Ann Oncol 2000, 11:743-747.

118. Shy ME, Chen L, Swan ER, Taube R, Krajewski KM, Herrmann D, Lewis RA, McDermott MP: Neuropathy progression in Charcot-Marie-Tooth disease type 1A. Neurology 2008, 70:378-383.

119. Garcia A, Combarros O, Calleja J, Berciano J: Charcot-Marie-Tooth disease type $1 \mathrm{~A}$ with $17 \mathrm{p}$ duplication in infancy and early childhood: a longitudinal clinical and electrophysiologic study. Neurology 1998, 50:1061-1067.

120. Padua L, Pareyson D, Aprile I, Cavallaro T, Quattrone A, Rizzuto N, Vita G, Tonali P, Schenone A: Natural history of CMT1A including QoL: A 2-year prospective study. Neuromuscul Disord 2008, 18:199-203.

121. Manfioletti G, Ruaro ME, Del Sal G, Philipson L, Schneider C: A growth arrest-specific (gas) gene codes for a membrane protein. Mol Cell Biol 1990, 10:2924-2930.

122. Choi BO, Koo SK, Park MH, Rhee H, Yang SJ, Choi KG, Jung SC, Kim HS, Hyun YS, Nakhro K, Lee HJ, Woo HM, Chung KW: Exome sequencing is an efficient tool for genetic screening of Charcot-Marie-Tooth disease. Hum Mutat 2012, 33:1610-1615.

123. Kohl B, Groh J, Wessig C, Wiendl H, Kroner A, Martini R: Lack of evidence for a pathogenic role of T-lymphocytes in an animal model for CharcotMarie-Tooth disease 1A. Neurobiol Dis 2010, 38:78-84.

124. Kohl B, Fischer S, Groh J, Wessig C, Martini R: MCP-1/CCL2 Modifies Axon Properties in a PMP22-Overexpressing Mouse Model for Charcot-MarieTooth 1A Neuropathy. Am J Pathol 2010, 176:1390-1399.

125. Ramaglia $V$, Tannemaat MR, De Kok M, Wolterman $R$, Vigar MA, King RH, Morgan BP, Baas F: Complement inhibition accelerates regeneration in a model of peripheral nerve injury. Mol Immunol 2009, 47:302-309.

126. Ramaglia V, Wolterman R, De Kok M, Vigar MA, Wagenaar-Bos I, King RH, Morgan BP, Baas F: Soluble complement receptor 1 protects the peripheral nerve from early axon loss after injury. Am J Pathol 2008, 172:1043-1052

127. Sereda MW, Meyer Zu Horste G, Suter U, Uzma N, Nave KA: Therapeutic administration of progesterone antagonist in a model of Charcot-MarieTooth disease (CMT-1A). Nat Med 2003, 9:1533-1537.

128. Meyer Zu Horste G, Prukop T, Liebetanz D, Mobius W, Nave KA, Sereda MW: Antiprogesterone therapy uncouples axonal loss from demyelination in a transgenic rat model of CMT1A neuropathy. Ann Neurol 2007, 61:61-72.

129. Passage $E$, Norreel JC, Noack-Fraissignes $P$, Sanquedolce $V$, Pizant J, Thirion X, Robaglia-Schlupp A, Pellissier JF, Fontes M: Ascorbic acid treatment corrects the phenotype of a mouse model of Charcot-Marie-Tooth disease. Nat Med 2004, 10:396-401.

130. Verhamme C, De Haan RJ, Vermeulen M, Baas F, De Visser M, Van Schaik IN: Oral high dose ascorbic acid treatment for one year in young CMT1A patients: a randomised, double-blind, placebo-controlled phase II trial. BMC Med 2009, 7:70

131. Micallef J, Attarian S, Dubourg O, Gonnaud PM, Hogrel JY, Stojkovic T, Bernard R, Jouve E, Pitel S, Vacherot F, Remec JF, Jomir L, Azabou E, AlMoussawi M, Lefebvre MN, Attolini L, Yaici S, Tanesse D, Fontes M, Pouget J, Blin O: Effect of ascorbic acid in patients with Charcot-Marie-Tooth disease type 1A: a multicentre, randomised, double-blind, placebocontrolled trial. Lancet Neurol 2009, 8:1103-1110.

132. Burns J, Ouvrier RA, Yiu EM, Joseph PD, Kornberg AJ, Fahey MC, Ryan MM: Ascorbic acid for Charcot-Marie-Tooth disease type 1A in children: a randomised, double-blind, placebo-controlled, safety and efficacy trial. Lancet Neurol 2009, 8:537-544.

133. Pareyson D, Reilly MM, Schenone A, Fabrizi GM, Cavallaro T, Santoro L, Vita G, Quattrone A, Padua L, Gemignani F, Visioli F, Laurà M, Radice D, Calabrese D, Hughes RA, Solari A: Ascorbic acid in Charcot-Marie-Tooth disease type 1A 
(CMT-TRIAAL and CMT-TRAUK): a double-blind randomised trial. Lancet Neurol 2011, 10:320-328.

134. Burns J, Ouvrier RA, Yiu EM, Ryan MM: Extended treatment of childhood Charcot-Marie-Tooth disease with high-dose ascorbic acid. J Peripher Nerv Syst 2011, 16:272-274.

135. Robertson JF, Willsher PC, Winterbottom L, Blamey RW, Thorpe S: Onapristone, a progesterone receptor antagonist, as first-line therapy in primary breast cancer. Eur J Cancer 1999, 35:214-218.

136. Sahenk Z, Nagaraja HN, McCracken BS, King WM, Freimer ML, Cedarbaum JM, Mendell JR: NT-3 promotes nerve regeneration and sensory improvement in CMT1A mouse models and in patients. Neurology 2005, 65:681-689.

137. Sahenk Z, Galloway G, Clark KR, Malik V, Rodino-Klapac LR, Kaspar BK, Chen L, Braganza C, Montgomery C, Mendell JR: AAV1.NT-3 Gene Therapy for Charcot-Marie-Tooth Neuropathy. Mol Ther 2014, 22:511-521.

138. Orfali W, Nicholson RN, Guiot MC, Peterson AC, Snipes GJ: An 8.5-kb segment of the PMP22 promoter responds to loss of axon signals during Wallerian degeneration, but does not respond to specific axonal signals during nerve regeneration. J Neurosci Res 2005, 80:37-46.

139. Jones EA, Lopez-Anido C, Srinivasan R, Krueger C, Chang LW, Nagarajan R, Svaren J: Regulation of the PMP22 gene through an intronic enhancer. J Neurosci 2011, 31:4242-4250.

140. Jang SW, Lopez-Anido C, MacArthur R, Svaren J, Inglese J: Identification of drug modulators targeting gene-dosage disease CMT1A. ACS Chem Biol 2012, 7:1205-1213.

141. Sereda M, Griffiths I, Puhlhofer A, Stewart H, Rossner MJ, Zimmerman F, Magyar JP, Schneider A, Hund E, Meinck HM, Suter U, Nave KA: A transgenic rat model of Charcot-Marie-Tooth disease. Neuron 1996, 16:1049-1060.

142. De Visser M, Verhamme C: Ascorbic acid for treatment in CMT1A: what's next? Lancet Neurol 2011, 10:291-293.

143. Chance PF, Alderson MK, Leppig KA, Lensch MW, Matsunami N, Smith B, Swanson PD, Odelberg SJ, Disteche CM, Bird TD: DNA deletion associated with hereditary neuropathy with liability to pressure palsies. Cell 1993 72:143-151.

144. Mouton P, Tardieu S, Gouider R, Birouk N, Maisonobe T, Dubourg O, Brice A, LeGuern E, Bouche P: Spectrum of clinical and electrophysiologic features in HNPP patients with the 17p11.2 deletion. Neurology 1999, 52:1440-1446.

145. Meretoja P, Silander K, Kalimo H, Aula P, Meretoja A, Savontaus ML: Epidemiology of hereditary neuropathy with liability to pressure palsies (HNPP) in south western Finland. Neuromuscul Disord 1997, 7:529-532.

146. Chance PF: Inherited focal, episodic neuropathies: hereditary neuropathy with liability to pressure palsies and hereditary neuralgic amyotrophy. Neuromolecular Med 2006, 8:159-174.

147. Gouider R, LeGuern E, Gugenheim M, Tardieu S, Maisonobe T, Leger JM, Vallat JM, Agid Y, Bouche P, Brice A: Clinical, electrophysiologic, and molecular correlations in 13 families with hereditary neuropathy with liability to pressure palsies and a chromosome $17 \mathrm{p} 11.2$ deletion. Neurology 1995, 45:2018-2023.

148. Lenssen PP, Gabreels-Festen AA, Valentijn $\sqcup$, Jongen PJ, Van Beersum SE, Van Engelen BG, Van Wensen PJ, Bolhuis PA, Gabreels FJ, Mariman EC: Hereditary neuropathy with liability to pressure palsies. Phenotypic differences between patients with the common deletion and a PMP22 frame shift mutation. Brain 1998, 121(8):1451-1458.

149. Gabreels-Festen AA, Gabreels FJ, Joosten EM, Vingerhoets HM, Renier WO: Hereditary neuropathy with liability to pressure palsies in childhood. Neuropediatrics 1992, 23:138-143.

150. Pareyson D, Scaioli V, Taroni F, Botti S, Lorenzetti D, Solari A, Ciano C, Sghirlanzoni A: Phenotypic heterogeneity in hereditary neuropathy with liability to pressure palsies associated with chromosome 17p11.2-12 deletion. Neurology 1996, 46:1133-1137.

151. Koike H, Hirayama M, Yamamoto M, Ito H, Hattori N, Umehara F, Arimura K, Ikeda S, Ando Y, Nakazato M, Kaji R, Hayasaka K, Nakagawa M, Sakoda S, Matsumura K, Onodera O, Baba M, Yasuda H, Saito T, Kira J, Nakashima K, Oka N, Sobue G: Age associated axonal features in HNPP with 17p11.2 deletion in Japan. J Neurol Neurosurg Psychiatry 2005, 76:1109-1114.

152. Li J, Krajewski K, Lewis RA, Shy ME: Loss-of-function phenotype of hereditary neuropathy with liability to pressure palsies. Muscle Nerve 2004, 29:205-210.

153. Kim SM, Chung KW, Choi BO, Yoon ES, Choi JY, Park KD, Sunwoo IN: Hereditary neuropathy with liability to pressure palsies (HNPP) patients of Korean ancestry with chromosome 17p11.2-p12 deletion. Exp Mol Med 2004, 36:28-35.

154. Dubourg O, Mouton P, Brice A, LeGuern E, Bouche P: Guidelines for diagnosis of hereditary neuropathy with liability to pressure palsies. Neuromuscul Disord 2000, 10:206-208.

155. Iwasaki $Y$, Iguchi $H$, Ikeda K, Kano O: CNS involvement in hereditary neuropathy with pressure palsies (HNPP). Neurology 2046, 2007:68

156. Poloni TE, Merlo IM, Alfonsi E, Marinou-Aktipi K, Botti S, Arrigo A, Taroni F, Ceroni M: Facial nerve is liable to pressure palsy. Neurology 1998 51:320-322.

157. Verhagen WI, Gabreels-Festen AA, Van Wensen PJ, Joosten EM, Vingerhoets HM, Gabreels FJ, De Graaf R: Hereditary neuropathy with liability to pressure palsies: a clinical, electroneurophysiological and morphological study. J Neurol Sci 1993, 116:176-184.

158. Davies DM: Recurrent peripheral nerve palsies in a family. Lancet 1954 267:266-268.

159. Winter WC, Juel VC: Hypoglossal neuropathy in hereditary neuropathy with liability to pressure palsy. Neurology 2003, 61:1154-1155.

160. Ohkoshi N, Kohno Y, Hayashi A, Wada T, Shoji S: Acute vocal cord paralysis in hereditary neuropathy with liability to pressure palsies. Neurology 2001, 56:1415

161. Verma A: Neuropathic scapuloperoneal syndrome (Davidenkow's syndrome) with chromosome 17p11.2 deletion. Muscle Nerve 2005, 32:668-671.

162. Bird TD: Hereditary Neuropathy with Liability to Pressure Palsies. In

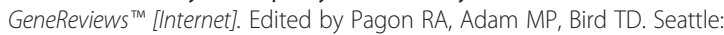
University of Washington, Seattle; 1993:2014.

163. Stogbauer F, Young P, Kuhlenbaumer G, De Jonghe P, Timmerman V: Hereditary recurrent focal neuropathies: clinical and molecular features. Neurology 2000, 54:546-551.

164. Infante J, Garcia A, Combarros O, Mateo JI, Berciano J, Sedano MJ, GutierrezRivas EJ, Palau F: Diagnostic strategy for familial and sporadic cases of neuropathy associated with 17p11.2 deletion. Muscle Nerve 2001, 24:1149-1155.

165. Andersson PB, Yuen E, Parko K, So YT: Electrodiagnostic features of hereditary neuropathy with liability to pressure palsies. Neurology 2000, 54:40-44.

166. Li J, Krajewski K, Shy ME, Lewis RA: Hereditary neuropathy with liability to pressure palsy: the electrophysiology fits the name. Neurology 2002, 58:1769-1773.

167. Hong YH, Kim M, Kim HJ, Sung JJ, Kim SH, Lee KW: Clinical and electrophysiologic features of HNPP patients with $17 \mathrm{p} 11.2$ deletion. Acta Neurol Scand 2003, 108:352-358.

168. Gabreels-Festen A, Wetering RV: Human nerve pathology caused by different mutational mechanisms of the PMP22 gene. Ann N Y Acad Sci 1999, 883:336-343.

169. Amato AA, Barohn RJ: Hereditary neuropathy with liability to pressure palsies: assocation with central nervous system demyelination. Muscle Nerve 1996, 19:770-773.

170. Sanahuja J, Franco E, Rojas-Garcia R, Gallardo E, Combarros O, Begue R, Granes $P$, Illa I: Central nervous system involvement in hereditary neuropathy with liability to pressure palsies: description of a large family with this association. Arch Neurol 1911-1914, 2005:62

171. Tackenberg B, Moller JC, Rindock H, Bien S, Sommer N, Oertel WH, Rosenow F, Schepelmann K, Hamer HM, Bandmann O: CNS involvement in hereditary neuropathy with pressure palsies (HNPP). Neurology 2006, 67:2250-2252

172. Nicholson GA, Valentijn $\sqcup$, Cherryson AK, Kennerson ML, Bragg TL, DeKroon RM, Ross DA, Pollard JD, McLeod JG, Bolhuis PA, Baas F: A frame shift mutation in the PMP22 gene in hereditary neuropathy with liability to pressure palsies. Nat Genet 1994, 6:263-266

173. Schenone A, Nobbio L, Mandich P, Bellone E, Abbruzzese M, Aymar F, Mancardi GL, Windebank AJ: Underexpression of messenger RNA for peripheral myelin protein 22 in hereditary neuropathy with liability to pressure palsies. Neurology 1997, 48:445-449.

174. Schenone A, Nobbio L, Caponnetto C, Abbruzzese M, Mandich P, Bellone $E_{\text {, }}$ Ajmar F, Gherardi G, Windebank AJ, Mancardi G: Correlation between PMP-22 messenger RNA expression and phenotype in hereditary neuropathy with liability to pressure palsies. Ann Neurol 1997, 42:866-872.

175. Jankelowitz SK, Burke D: Pathophysiology of HNPP explored using axonal excitability. J Neurol Neurosurg Psychiatry 2013, 84:806-812. 
176. Bai Y, Zhang X, Katona I, Saporta MA, Shy ME, O'Malley HA, Isom LL, Suter U, Li J: Conduction block in PMP22 deficiency. J Neurosci 2010, 30:600-608.

177. Hooper DR, Lawson W, Smith L, Baker SK: Sonographic features in hereditary neuropathy with liability to pressure palsies. Muscle Nerve 2011, 44:862-867.

178. Ginanneschi F, Filippou G, Giannini F, Carluccio MA, Adinolfi A, Frediani B, Dotti MT, Rossi A: Sonographic and electrodiagnostic features of hereditary neuropathy with liability to pressure palsies. J Peripher Nerv Syst 2012, 17:391-398.

179. Stockton DW, Meade RA, Netscher DT, Epstein MJ, Shenaq SM, Shaffer LG, Lupski JR: Hereditary neuropathy with liability to pressure palsies is not a major cause of idiopathic carpal tunnel syndrome. Arch Neurol 2001, 58:1635-1637.

180. Kuhlenbaumer G, Hannibal MC, Nelis E, Schirmacher A, Verpoorten N, Meuleman J, Watts GD, De Vriendt E, Young P, Stogbauer F, Halfter H, Irobi J, Goossens D, Del-Favero J, Betz BG, Hor H, Kurlemann G, Bird TD, Airaksinen E, Mononen T, Serradell AP, Prats JM, Van Broeckhoven C, De Jonghe P, Timmerman V, Ringelstein EB, Chance PF: Mutations in SEPT9 cause hereditary neuralgic amyotrophy. Nat Genet 2005, 37:1044-1046.

181. Cruz-Martinez A, Arpa J, Palau F: Peroneal neuropathy after weight loss. J Peripher Nerv Syst 2000, 5:101-105.

182. Kalfakis N, Panas M, Karadima G, Floroskufi P, Kokolakis N, Vassilopoulos D: Hereditary neuropathy with liability to pressure palsies emerging during vincristine treatment. Neurology 2002, 59:1470-1471.

183. Russo M, Laura M, Polke JM, Davis MB, Blake J, Brandner S, Hughes RA, Houlden H, Bennett DL, Lunn MP, Reilly MM: Variable phenotypes are associated with PMP22 missense mutations. Neuromuscul Disord 2011, 21:106-114.

184. Li J, Parker B, Martyn C, Natarajan C, Guo J: The PMP22 gene and its related diseases. Mol Neurobiol 2013, 47:673-698.

185. De Vries SD, Verhamme C, Van Ruissen F, Van Paassen BW, Arts WF, Kerkhoff $H$, Van Engelen BG, Lammens M, De Visser M, Baas F, van der Kooi AJ: The phenotype of the Gly94fsX222 PMP22 insertion. J Peripher Nerv Syst 2011, 16:113-118.

186. Saporta AS, Sottile SL, Miller LJ, Feely SM, Siskind CE, Shy ME: CharcotMarie-Tooth disease subtypes and genetic testing strategies. Ann Neurol 2011, 69:22-33.

187. Nelis E, Holmberg B, Adolfsson R, Holmgren G, Van Broeckhoven C: PMP22 Thr(118)Met: recessive CMT1 mutation or polymorphism? Nat Genet 1997, 15:13-14.

188. Parman Y, Plante-Bordeneuve V, Guiochon-Mantel A, Eraksoy M, Said G: Recessive inheritance of a new point mutation of the PMP22 gene in Dejerine-Sottas disease. Ann Neurol 1999, 45:518-522.

189. Numakura C, Lin C, Oka N, Akiguchi I, Hayasaka K: Hemizygous mutation of the peripheral myelin protein 22 gene associated with Charcot-MarieTooth disease type 1. Ann Neurol 2000, 47:101-103.

doi:10.1186/1750-1172-9-38

Cite this article as: van Paassen et al.: PMP22 related neuropathies: Charcot-Marie-Tooth disease type 1A and Hereditary Neuropathy with liability to Pressure Palsies. Orphanet Journal of Rare Diseases 2014 9:38.

\section{Submit your next manuscript to BioMed Central and take full advantage of:}

- Convenient online submission

- Thorough peer review

- No space constraints or color figure charges

- Immediate publication on acceptance

- Inclusion in PubMed, CAS, Scopus and Google Scholar

- Research which is freely available for redistribution

Submit your manuscript at www.biomedcentral.com/submit
( Biomed Central 